\title{
Clinical validation of a link between TNF- $\alpha$ and the glycosylation enzyme core 2 GIcNAc-T and the relationship of this link to diabetic retinopathy
}

\author{
B. M. Ben-Mahmud • W. H. Chan - R. M. Abdulahad • \\ A Datti • A Orlacchio • E. M. Kohner • R Chibber
}

Received: 19 September 2005 / Accepted: 9 May 2006 / Published online: 11 July 2006

(C) Springer-Verlag 2006

\begin{abstract}
Aims/hypothesis Increasing evidence suggests that chronic, subclinical inflammation plays an important role in the pathogenesis of diabetic retinopathy. We recently reported that a glycosylating enzyme, core $2 \beta-1,6-N$-acetylglucosaminyltransferase (core 2 GlcNAc-T), is implicated in increased leucocyte-endothelial cell adhesion in diabetic retinopathy via an upregulation mechanism controlled by TNF- $\alpha$.

Subjects, materials and methods We examined the functional link between circulating TNF- $\alpha$ and the activity and phosphorylation of core 2 GlcNAc-T in polymorphonuclear leucocytes of patients with type 1 and type 2 diabetes.

Results Plasma levels of $\mathrm{TNF}-\alpha$, although similar in patients with type 1 and type 2 diabetes, were significantly higher than in age-matched healthy controls, and correlated well with the severity of retinopathy. Core 2 GlcNAc-T activity followed the same trend and was associated with phosphorylation of the enzyme. Finally, the observation that TNF- $\alpha$ levels are also linked to glycaemic values suggests that in patients, as well as in vitro, the glycosylation-mediated cell adhesion process that plays a role in diabetic retinopathy may involve glucose- and TNF- $\alpha$ -
\end{abstract}

B. M. Ben-Mahmud • W. H. Chan • R. M. Abdulahad •

E. M. Kohner $\cdot$ R. Chibber $(\square)$

Cardiovascular Division,

2nd Floor, New Hunt's House,

GKT School of Biomedical and Health Sciences,

Guy's Campus, King's College London,

London SE1 1UL, UK

e-mail: rakesh.chibber@kcl.ac.uk

\footnotetext{
A. Datti $\cdot$ A. Orlacchio

Department of Experimental Medicine

and Biochemical Sciences, University of Perugia,

Perugia, Italy
}

induced protein kinase $\beta 2$ activation, and subsequently raise activity of core 2 GlcNAc-T through increased enzyme phosphorylation.

Conclusions/interpretation Our results reveal a novel rationale towards a specific treatment of diabetic retinopathy, based on the inhibition of core 2 GlcNAc-T activity and/or the blockage of cognate glycans.

Keywords $\beta-1,6-N$-acetylglucosaminyltransferase .

C-reactive protein $\cdot$ Hyperglycaemia $\cdot$ Leucocyte .

Non-proliferative diabetic retinopathy $\cdot$ Proliferative diabetic retinopathy S Subclinical inflammation $\cdot \mathrm{TNF}-\alpha$.

Type 1 diabetes · Type 2 diabetes

\section{Abbreviations}

Core 2 core $2 \beta-1,6-N$-acetylglucosaminyltransferase GlcNAc-T

CRP C-reactive protein

NPDR non-proliferative diabetic retinopathy

PDR proliferative diabetic retinopathy

PKC protein kinase C

PMN polymorphonuclear

PSGL-1 P-selectin glycoprotein ligand-1

\section{Introduction}

Diabetic retinopathy is a leading cause of blindness for working-age people living in Western countries [1]. As shown by fluorescein angiography, an early clinical feature of this disease is the occlusion of capillaries [2, 3], although the pathogenic mechanism whereby this arises remains unclear. However, growing evidence suggests that retinopathy is a low-grade, chronic inflammatory condition associ- 
ated with increased leucocyte entrapment in retinal capillaries and areas of capillary non-perfusion followed by endothelial cell damage [4-7].

Earlier studies have demonstrated that structural changes in $O$-linked carbohydrates expressed on the surface of leucocytes play a prominent role in controlling adhesion to endothelial cells $[8,9]$. In this regard, our group has described, through use of an in vitro cell-based assay method, that plasma of diabetic patients affected by retinopathy causes a catalytic upregulation of a key glycosylating enzyme of the $O$-linked pathway, i.e. core 2 $\beta-1,6-N$-acetylglucosaminyltransferase (core 2 GlcNAc-T), leading to a comparable increase of cell adhesion properties [10]. The activity of core 2 GlcNAc-T is significantly higher in type 1 and type 2 diabetic patients with retinopathy [11]. Furthermore, we have reported biochemical studies suggesting that TNF- $\alpha$ modulates core 2 GlcNAc-T activity via protein phosphorylation mediated by serine/threonine protein kinase $\mathrm{C} \beta 2$ (PKC $\beta 2)[10,12]$.

The present study was designed to clinically validate the association between plasma levels of TNF- $\alpha$, phosphorylation of leucocytic core 2 GlcNAc-T and corresponding enzyme activity at different stages of retinopathy in diabetic patients.

\section{Subjects, materials and methods}

\section{Subjects}

This study included a total of 25 type 1 and 41 type 2 diabetic patients recruited from the Diabetes Outpatient Clinic and the Eye Unit at St Thomas' Hospital, London, UK. Age-matched non-diabetic healthy controls $(n=15)$ were found among the accompanying relatives of the patients or from hospital employees. The duration of type 1 and type 2 diabetes was $18.9 \pm 2.2$ and $9.2 \pm 1.8$ years, respectively. The levels of severity of retinopathy were determined according to the lesions as non-proliferative diabetic retinopathy (NPDR) or proliferative diabetic retinopathy (PDR). Informed, written consent was obtained from all participants in our investigation, which was approved by Guy's and St Thomas' Medical Ethics Committee and carried out in accordance with the Declaration of Helsinki as revised in 2000 (http://www.wma.net/e/ policy/b3.htm).

\section{Collection of blood and preparation of plasma}

Whole blood was drawn and collected in EDTA tubes. Blood glucose was measured using a glucose analyser (Clandon Scientific; YSI, Yellow Springs, OH, USA). Plasma was isolated after density gradient centrifugation over Histopaque 1070 (Sigma, Poole, UK). Briefly, $10 \mathrm{ml}$ of whole blood were layered onto an equal volume of Histopaque and centrifuged (Heraeus, Brentwood, Essex, UK) at $400 \times g$ for $30 \mathrm{~min}$. Plasma above the polymorphonuclear (PMN) leucocyte-rich buffy coat was carefully removed under sterile conditions and stored at $-20^{\circ} \mathrm{C}$ until used for experiments. The PMN leucocyte-rich buffy coat was carefully removed and resuspended in PBS. After centrifugation at $400 \times g$ for $15 \mathrm{~min}$, the pellet was stored at $-20^{\circ} \mathrm{C}$ until used in the assay for core 2 GlcNAc-T activity.

\section{Measurement of core 2 GlcNAc-T activity}

To measure core 2 GlcNAc-T activity, leucocytes were washed in PBS, frozen and lysed in $0.9 \% \mathrm{NaCl}, 0.4 \%$ Triton $\mathrm{X}-100$ at $0^{\circ} \mathrm{C}$. The activity of core 2 GlcNAc-T was then measured as described previously [8]. Endogenous activity of core 2 GlcNAc-T was measured in the absence of the added acceptor. The specific activity was expressed as picomoles per hour per milligram cell protein. In each case, the protein concentration was determined using a BCA Protein Assay Kit (Sigma, Poole, Dorset, UK).

Immunoassays

Plasma concentrations of TNF- $\alpha$ were measured in the diabetic patients and age-matched healthy controls using a commercially available ELISA kit (R\&D Systems, Abingdon, Oxon, UK), which was standardised and implemented based on the manufacturer's instructions. Sensitivity of the kit for plasma concentrations of TNF- $\alpha$, expressed as minimum detectable dose, was $0.12 \mathrm{pg} / \mathrm{ml}$, while reproducibility of the assay method, evaluated as inter-assay variability, was quantified by a $10 \% \mathrm{CV}$.

C-reactive protein (CRP) was determined using a highsensitivity anti-CRP monoclonal antibody kit with immunonephelometry (Dade Behring, Milton Keynes, Bucks, UK). This method had a lower detection limit of $0.2 \mathrm{mg} / \mathrm{l}$ and an inter-assay $\mathrm{CV}$ of $2.8 \%$.

Immunoprecipitation of core 2 GlcNAc-T and Western blot analysis

For core 2 GlcNAc-T immunoprecipitation, as well as for Western blots, a polyclonal antibody against core 2 GlcNAc-T was used [12]. Cells were lysed on ice in lysis buffer $(20 \mathrm{mmol} / \mathrm{l}$ Tris-HCl, pH 7.4, $1 \%$ Triton X-100, $150 \mathrm{mmol} / 1 \mathrm{NaCl}, 1 \mathrm{mmol} / \mathrm{l}$ EDTA, $1 \mathrm{mmol} / \mathrm{l}$ EGTA, $0.2 \mathrm{mmol} / 1$ sodium vandate, $1 \mathrm{mmol} / 1$ phenylmethylsulphonyl fluoride, $1 \mu \mathrm{g} / \mathrm{ml}$ aprotinin and $10 \mu \mathrm{g} / \mathrm{ml}$ leupeptin). The lysate was incubated at $4^{\circ} \mathrm{C}$ for 20 min with constant agitation and insoluble material removed by centrifugation 
Table 1 Clinical and metabolic characteristics of the study population

\begin{tabular}{lll}
\hline & Type 1 diabetes & Type 2 diabetes \\
\hline$n$ & 25 & 41 \\
Sex (F/M) & $11 / 14$ & $18 / 23$ \\
Age & $55.1 \pm 2.7$ & $59.8 \pm 2.1$ \\
Known duration of diabetes & $18.9 \pm 2.2$ & $9.2 \pm 1.8$ \\
$\quad$ years) & & \\
HbA 1 (\%) & $6.2 \pm 0.15$ & $6.0 \pm 0.11$ \\
BMI $\left(\mathrm{kg} / \mathrm{m}^{2}\right)$ & $23.7 \pm 0.72$ & $28.7 \pm 0.79$ \\
Diabetic retinopathy & & \\
Absent & 4 & 16 \\
NPDR & 12 & 16 \\
PDR & 9 & 9 \\
Diabetic nephropathy & & \\
Absent & 25 & 41 \\
Incipient & 0 & 0 \\
Diabetic neuropathy & 6 & 4 \\
Ischaemic heart disease & 5 & 3 \\
Peripheral vascular disease & 3 & \\
\hline
\end{tabular}

Data are expressed as number, percentage and means \pm SEM

$\left(14,000 \times g\right.$ for $5 \mathrm{~min}$ at $\left.4^{\circ} \mathrm{C}\right)$. The clarified lysate was incubated with Protein A-Sepharose Cl-4B-conjugated primary antibody for $2 \mathrm{~h}$ with constant agitation at $4^{\circ} \mathrm{C}$. The immunoprecipitates were washed with Tris-buffered saline $(10 \mathrm{mmol} / \mathrm{l}$ Tris- $\mathrm{HCl}, \mathrm{pH}$ 7.4, $150 \mathrm{mmol} / \mathrm{l} \mathrm{NaCl})$ containing $0.5 \%$ Triton $\mathrm{X}-100$, resuspended in $2 \times \mathrm{SDS}-$ PAGE sample buffer and analysed by SDS-PAGE. After immunodetection of core 2 GlcNAc-T, the membranes were stripped in a buffer containing $50 \mathrm{mmol} / 1$ Tris-HCL, $2 \%$ SDS and $100 \mathrm{mmol} / 1$ mercaptoethanol at $55^{\circ} \mathrm{C}$ for $30 \mathrm{~min}$, washed and immunoblotted with anti-phosphoserine antibody (Chemicon, Chandlers Ford, Hants, UK). Immunoreactive bands were quantified by scanning densitometrically and calculating the density of individual bands using ImageQuant software (Molecular Dynamics, Kemsing, Kent, UK). The level of serine phosphorylation was expressed as a ratio of the intensity of the phosphorylation immunoreactive band to the intensity of core 2 GlcNAc-T immunoreactive bands.

Protein measurement

Total protein was measured using a BCA protein assay kit.

Statistical analysis

The statistical software Graph Pad Prism version 3.0 was used (GraphPad Software, San Diego, CA, USA. An unpaired two-tailed Student's $t$-test was used to test the significance of variables. Linear regression and correlation were used to evaluate the relationship between two variables. Data are expressed as means \pm SEM of measurements in the different experiments. Differences were considered statistically significant at $p<0.05$.

\section{Results}

Subjects

Table 1 shows the baseline clinical characteristics of patients with type 1 and type 2 diabetes recruited for this study.

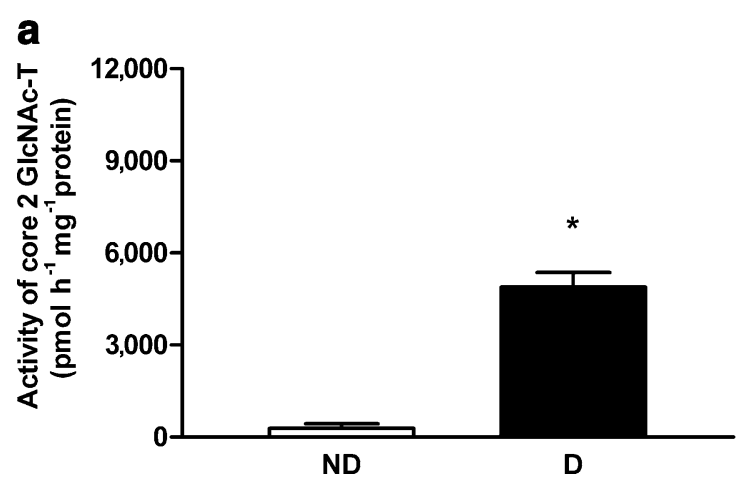

Fig. 1 Activity of core 2 GlcNAc-T in PMN leucocytes is associated with severity of diabetic retinopathy. PMN cells were isolated from diabetic patients with no retinopathy $(N R, n=20)$, non-proliferative diabetic retinopathy $(N P D R, n=28)$ and proliferative diabetic retinopathy $(P D R, n=18)$, and age-matched healthy controls $(N D, n=15)$. The activity of core 2 GlcNAc-T was measured in lysates and expressed as

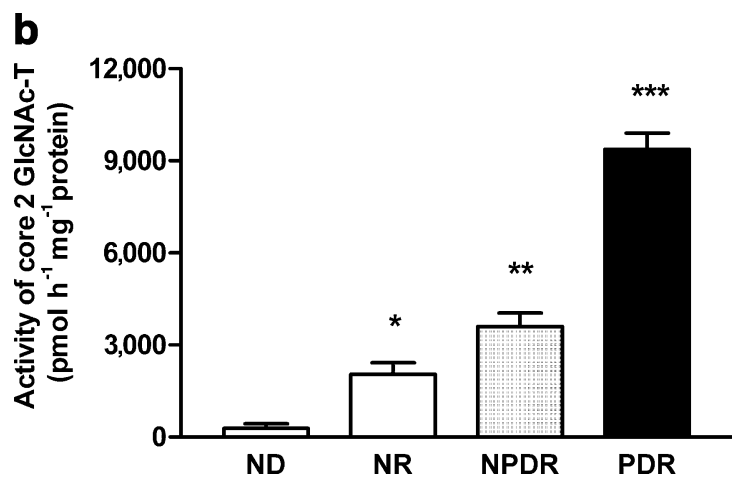

picomoles per hour per milligram protein. a The activity of core 2 GlcNAc-T in PMN cells from patients with type 1 and type 2 diabetes $(D, n=66$ and age-matched healthy controls $(N D, n=15)$. Means \pm SEM; ${ }^{*} p<0.0001$. b Relationship between the activity of core 2 GlcNAc-T in $\mathrm{PMN}$ cells and severity of diabetic retinopathy. Means \pm SEM: ${ }^{*} p=0.0007$ vs ND; $* * p=0.0138$ vs NR; $* * * p<0.0001$ vs NPDR 
Activity of core 2 GlcNAc-T in leucocytes of diabetic patients

The activity of core 2 GlcNAc-T was several-fold higher in PMN leucocytes of patients with type 1 and type 2 diabetes than in those of healthy control subjects $(4,888 \pm 475$ vs $287 \pm 147 \mathrm{pmol} \cdot \mathrm{h}^{-1} \cdot \mathrm{mg}^{-1}$ protein, $p<0.0001$ ) (Fig. 1a). Furthermore, we observed a close relationship between enzyme activity in PMN leucocytes and severity of diabetic
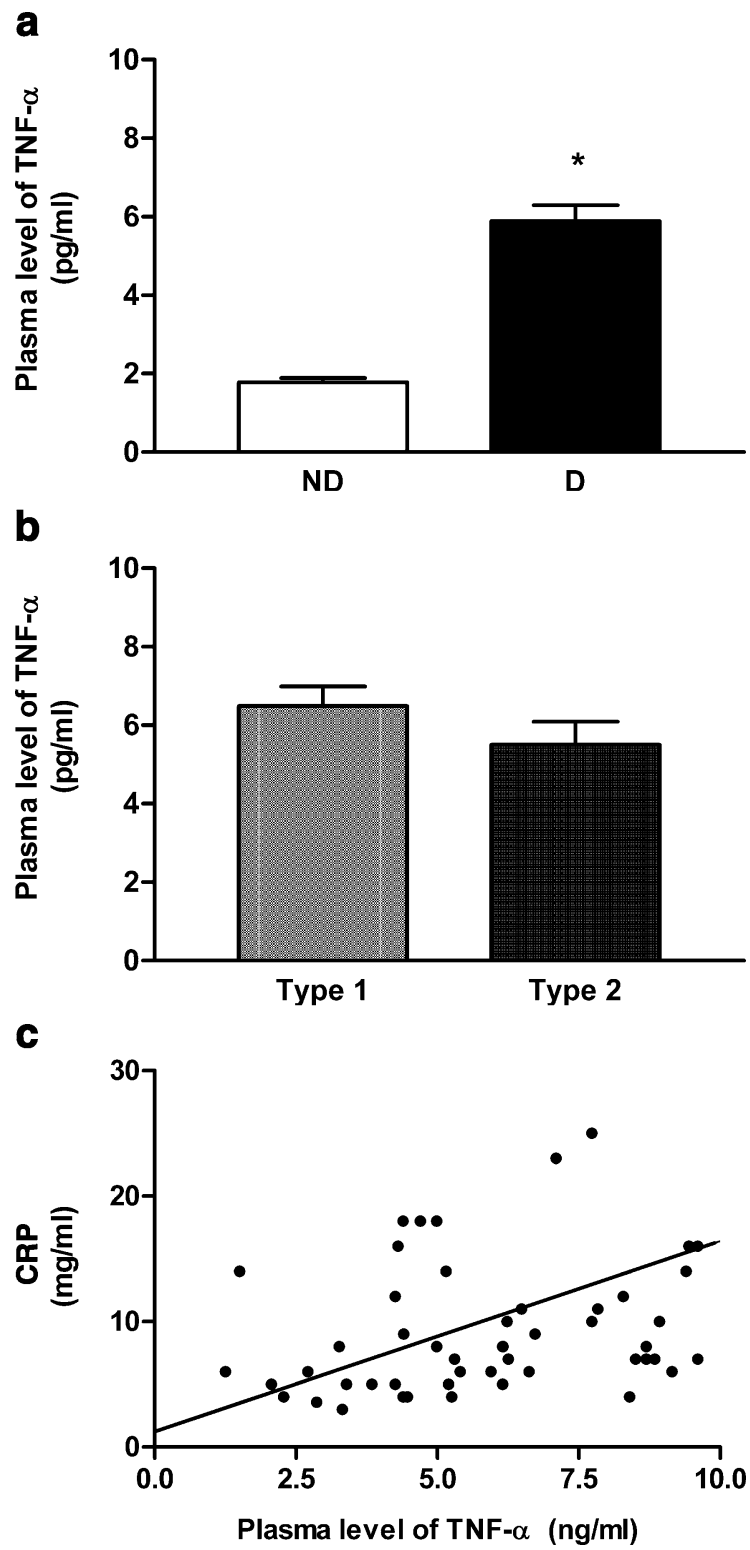

Fig. 2 Plasma levels of TNF- $\alpha$ are higher in diabetic patients than in age-matched healthy control subjects. EDTA-plasma samples were collected and stored at $-80^{\circ} \mathrm{C}$. a Plasma levels of TNF- $\alpha$ in diabetic patients $(D, n=66)$ vs age-matched healthy controls $(N D, n=15)$. Means \pm SEM; ${ }^{*} p<0.0001$. b Plasma levels of TNF- $\alpha$ in patients with type $1(n=25)$ and type $2(n=41)$ diabetes. Means \pm SEM; difference non-significant. c Significant relationship $(r=0.4126, p=0.0024)$ between plasma levels of TNF- $\alpha$ and plasma levels of CRP. Data points represent single plasma samples retinopathy (Fig. 1b). PMN leucocytes of diabetic patients with PDR $(n=18)$ exhibited core 2 GlcNAc-T activity that was approximately 2.6-fold higher than that from patients with NPDR $(n=23)(9,372 \pm 532$ vs $3,601 \pm 443, p<0.0001)$.

Plasma TNF- $\alpha$ in diabetic patients

Values of circulating TNF- $\alpha$ were significantly higher (Fig. 2a) in diabetic patients $(5.89 \pm 0.41 \mathrm{pg} / \mathrm{ml}, n=51)$ than in healthy subjects $(1.78 \pm 0.11 \mathrm{pg} / \mathrm{ml} ; p<0.0001, n=15)$. Conversely, our study revealed no evidence of differential TNF- $\alpha$ levels in plasma from patients with type 1 and type 2 diabetes (Fig. 2b). There was a positive correlation between plasma levels of CRP and TNF- $\alpha \quad(r=0.4126$, $p=0.0024$ ) (Fig. 2c). CRP is the main acute-phase protein and elevated CRP levels are an indicator of systemic inflammation.

Data analysis showed a significant, positive correlation between TNF- $\alpha$ and the severity of diabetic retinopathy (Fig. 3). In this regard, plasma levels of TNF- $\alpha$ in diabetic patients with PDR $(n=16)$ were significantly higher than in subjects affected by NPDR $(n=23)(8.24 \pm 0.38$ vs $5.73 \pm$ $0.56 \mathrm{pg} / \mathrm{ml})$.

Positive correlation between plasma TNF- $\alpha$ levels and core 2 GlcNAc-T activity

We have recently reported that in U937 cells, used as a model of circulating leucocytes, exogenous TNF- $\alpha$ causes a dose-dependent elevation of core 2 GlcNAc-T activity via PKC $\beta 2$-phosphorylation of the enzyme protein [12]. To confirm the implication of this pathway in diabetic patients affected by retinopathy, plasma levels of TNF- $\alpha$ were compared with the activity of core 2 GlcNAc-T measured in PMN cells. Figure 4 shows that the two values were closely related $(r=0.540, p<0.0001)$. Additionally, data

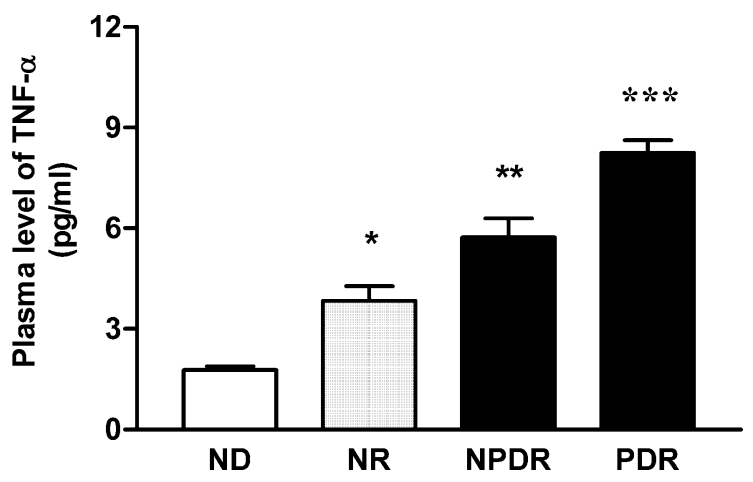

Fig. 3 Plasma levels of TNF- $\alpha$ strongly correlate with the severity of diabetic retinopathy. Plasma and PMN leucocytes were isolated from total blood of diabetic patients with no retinopathy $(N R, n=20)$, nonproliferative diabetic retinopathy $(N P D R, n=28)$, proliferative diabetic retinopathy $(P D R, n=18)$, and age-matched healthy controls $(N D$, $n=15)$. Means \pm SEM: ${ }^{*} p=0.0005$ vs ND; ${ }^{* *} p=0.018$ vs NR; $* * * p=0.0018$ vs NPDR 


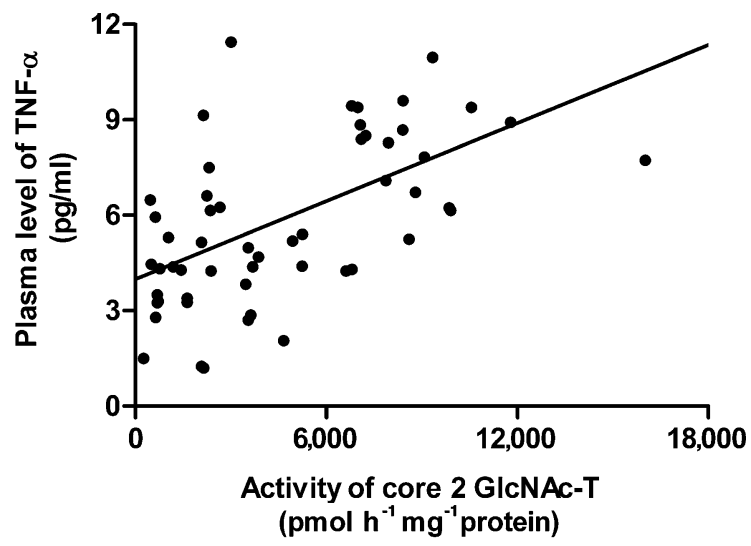

Fig. 4 Plasma levels of TNF- $\alpha$ strongly correlate with the activity of core 2 GlcNAc-T in PMN leucocytes of diabetic patients. Plasma and PMN cells were isolated from total blood of patients with type 1 and type 2 diabetes $(n=66)$. Each data point represents the TNF- $\alpha$ level of a single plasma sample. Activity of core 2 GlcNAc-T was measured in the PMN cell lysates and expressed as picomoles per hour per milligram protein $(r=0.540, p<0.0001)$

analysis indicated a close correlation between serine phosphorylation of the enzyme protein and both the level of TNF- $\alpha$ (Fig. $5 b$ ) and the activity of core 2 GlcNAc-T (Fig. 5c) $(r=0.434, p=0.00386$ and $r=0.412, p=0.017$, respectively), thereby substantiating the results previously obtained in vitro.

Correlation between glycaemia and core 2 GlcNAc-T activity and plasma TNF- $\alpha$ levels

Blood glucose showed a significant correlation with the activity of core 2 GlcNAc-T in PMN leucocytes $(r=0.572$, $p=0.0003$ ) (Fig. 6a), and also plasma TNF- $\alpha$ levels $(r=0.423, p=0.0248)$ (Fig. 6b) in diabetic patients.

\section{Discussion}

The present study validates the pivotal role of circulating plasma TNF- $\alpha$ in the induction of a key glycosyltransferase of the $O$-linked glycosylation pathway, namely core 2 GlcNAc-T, which is associated with the biosynthesis of carbohydrate moieties affecting cell adhesion events. In this regard, the functional significance of higher core 2 GlcNAc-T activity, and subsequent appearance of cognate $O$-glycans, during the initial course of the inflammatory cascade has been well documented [13, 14].

The extent of the increase in core 2 GlcNAc-T activity in leucocytes of diabetic patients is similar to that observed in a number of physiological and pathological events, such as immune responses, diabetic cardiomyopathy and cancer, where a common element of these conditions is the altered dynamics of cell-cell or cell-matrix [15-18] interactions. a

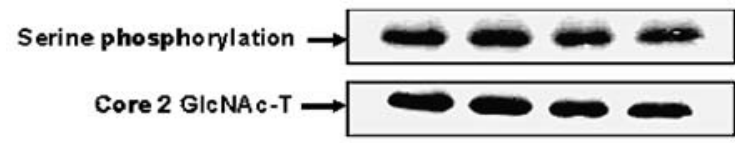

b
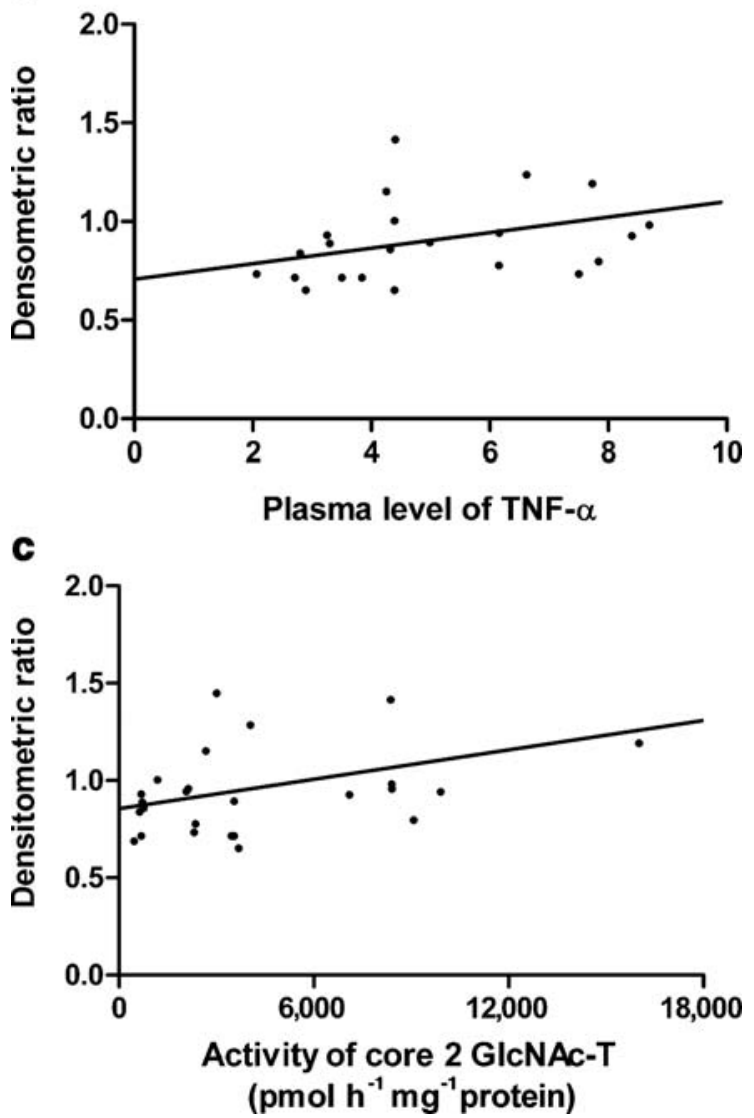

Fig. 5 Plasma levels of TNF- $\alpha$ are associated with the phosphorylation of core 2 GlcNAc-T in PMN leucocytes of diabetic patients. Plasma and PMN cells were isolated from total blood of patients with type 1 and type 2 diabetes $(n=22)$. a Core 2 GlcNAc-T was immunoprecipitated from PMN cell lysates, followed by immunoblotting with anti-phosphoserine antibody. Blots were re-probed with anti-core 2 GlcNAc-T antibody. The blots were analysed densitometrically and level of phosphorylation expressed as a ratio (intensity of phosphorylation immunoreactive band : intensity of core 2 GlcNAc-T immunoreactive band). b Significant relationship between the levels of TNF- $\alpha$ in plasma and phosphorylation of core 2 GlcNAc-T in PMN cells of diabetic patients $(r=0.434, p=0.00386)$. c Significant relationship between the activity and phosphorylation of core 2 GlcNAc-T in leucocytes of diabetic patients $(r=0.412, p=0.017)$. Data points $(\mathbf{b}, \mathbf{c})$ represent the TNF- $\alpha$ level in single plasma samples

The central and causal role of leucocytes in vaso-occlusive processes and endothelial cell injury leading to the pathogenesis of diabetic retinopathy suggests a physiological significance of the enzyme in diabetes, probably through P-selectin glycoprotein ligand-1 (PSGL-1)-mediated adhesion events [11].

Using U937 cells as a model of circulating leucocytes, our group has previously shown that a human recombinant 


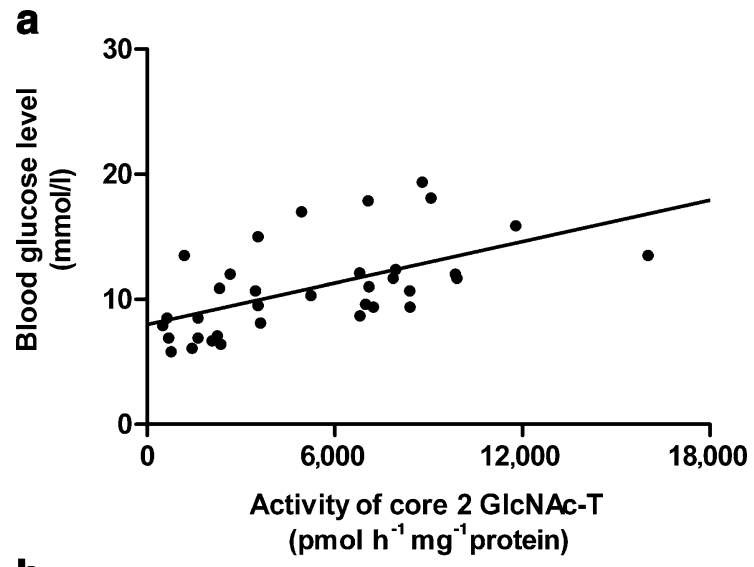

b

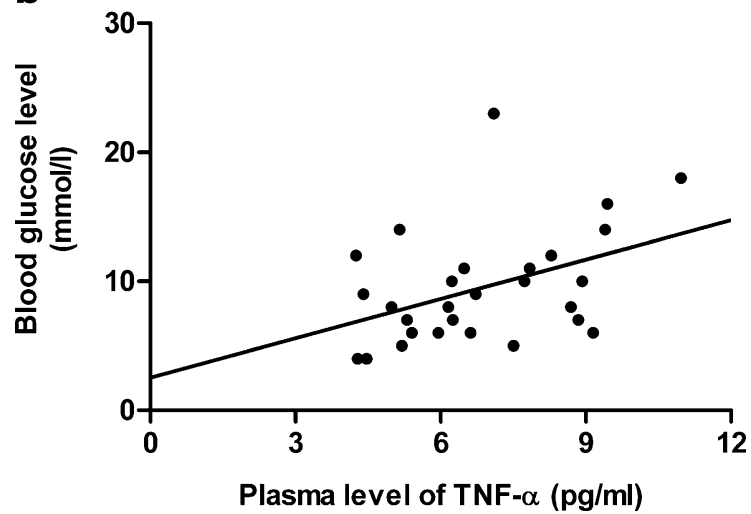

Fig. 6 Activity of core 2 GlcNAc-T in PMN leucocytes and plasma levels of TNF- $\alpha$ strongly correlate with blood glucose in diabetic patients. Plasma and PMN cells were isolated from total blood of patients with type 1 and type 2 diabetes $(n=28)$. Each data point represents the TNF- $\alpha$ level of a single plasma sample. a Significant relationship between blood glucose and the activity of core 2 GlcNAc-T in PMN cells $(r=0.572, p=0.0003)$. b Significant relationship between blood glucose and plasma levels of TNF- $\alpha(r=0.423, p=0.0248)$

version of TNF- $\alpha$ controls core 2 GlcNAc-T activity in a dose-dependent fashion via PKC $\beta 2$-phosphorylation of the enzyme protein [12]. This study confirms that, in diabetic patients, the functional link between plasma TNF- $\alpha$ and leucocytic core 2 GlcNAc-T through protein phosphorylation closely reflects the correlation observed in vitro. Consistent with previous reports [19-22], we noted significantly higher levels of TNF- $\alpha$ in the plasma of patients affected by either type 1 or type 2 diabetes vs healthy control subjects.

Our results indicate that this overzealous production of the cytokine, which may be released from various sources such as activated leucocytes, adipocytes and endothelial cells, is directly correlated with glucose values. This is in agreement with a previous report, which showed that chronic high glucose can dramatically increase levels of circulating TNF- $\alpha$ in human monocytic cells via oxidant stress-dependent and -independent pathways [23]. It is conceivable that higher levels of glucose and/or TNF- $\alpha$ may upregulate expression of adhesion molecules, such as
E-selectin, intracellular adhesion molecule-1 (ICAM-1) and vascular cell adhesion molecule-1 [24-26], on the surface of endothelial cells and cause leucocyte adhesion to the diabetic retinal vasculature. In this regard, leucocytes of CD18 and ICAM-1 knock-out mice exhibited significantly decreased adhesion properties, which was associated with fewer damaged endothelial cells and less vascular leakage [27]. The contribution of TNF- $\alpha$ to the onset and progression of diabetic retinopathy is clearly supported by a number of previous studies [28-34], suggesting the therapeutic potential of anti-inflammatory treatments.

The demonstration that glucose levels, plasma TNF- $\alpha$ and core 2 GlcNAc-T activity are functionally linked with diabetic retinopathy confirms the physiological relevance of the cytokine, and the involvement of a downstream, glycosylation-mediated pathway in the onset and/or progression of the disease. Although the relative importance of this mechanism in diabetic retinopathy has yet to be elucidated, the validation of the in vitro system based on U937 cells allows further studies to be carried out in this regard. The use of core 2 GlcNAc-T gene-silencing strategy with RNA interference (RNAi) is a potential strategy, as well as the blockage of PSGL-1, the enzyme's predominant substrate expressed on the cell surface of leucocytes, which binds to P-selectin and primarily mediates the rolling phase of the adhesion cascade $[35,36]$. These studies would provide insights regarding the possible use of small molecule inhibitors of core 2 GlcNAc-T as therapeutics.

Given the wide spectrum of biological activities shown by TNF- $\alpha$ [37] and, in particular, its important role in the general responses of the immune system, our results reveal a novel rationale for a specific treatment of diabetic retinopathy.

Acknowledgements We thank E. Rayman (Blood Test Department, St Thomas' Hospital) for blood samples from diabetic patients. This study was supported in part by Charities Advisory Trust (London, UK) and Guy's \& St Thomas' Charitable Foundation.

\section{References}

1. Klein R, Klein BE, Moss SE, Davis MD, DeMets DL (1989) The Wisconsin Epidemiologic Study of Diabetic Retinopathy. $\mathrm{X}$. Four-year incidence and progression of diabetic retinopathy when age at diagnosis is 30 years or more. Arch Ophthalmol 107:244-249

2. Davis MD (1992) Diabetic retinopathy. A clinical overview. Diabetes Care 15:1844-1874

3. Kohner EM, Chibber R (1999) Diabetic retinopathy. In Tooke JE (ed) Diabetic angiopathy. Oxford University Press, pp 233-247

4. Miyamoto K, Khosrof S, Bursell SE et al (1999) Prevention of leukostasis and vascular leakage in streptozotocin-induced diabetic retinopathy via intercellular adhesion molecule-1 inhibition. Proc Natl Acad Sci U S A 96:10836-10841 
5. Lutty GA, Cao J, McLeod DS (1997) Relationship of polymorphonuclear leukocytes to capillary dropout in the human diabetic choroid. Am J Pathol 151:707-714

6. Joussen AM, Murata T, Tsujikawa A, Kirchhof B, Bursell SE, Adamis AP (2001) Leukocyte-mediated endothelial cell injury and death in the diabetic retina. Am J Pathol 158:147-152

7. Ishida S, Yamashiro K, Usui T et al (2003) Leukocytes mediate retinal vascular remodeling during development and vaso-obliteration in disease. Nat Med 9:781-788

8. Williams D, Schachter H (1980) Mucin synthesis. I. Detection in canine submaxillary glands of an $\mathrm{N}$-acetylglucosaminyltransferase which acts on mucin substrates. J Biol Chem 255:11247-11252

9. Mukasa R, Homma T, Hosono O et al (1999) Human $T$ lymphocyte populations which bind to $\mathrm{P}$ - or E-selectin are enriched with cells expressing core 2 O-glycans. Immunol Lett 67:117-124

10. Ben-Mahmud BM, Mann GE, Datti A, Orlacchio A, Kohner EM, Chibber R (2004) Tumor necrosis factor-alpha in diabetic plasma increases the activity of core 2 GlcNAc-T and adherence of human leukocytes to retinal endothelial cells: significance of core 2 GlcNAc-T in diabetic retinopathy. Diabetes 53:2968-2976

11. Chibber R, Ben-Mahmud BM, Coppini D, Christ E, Kohner EM (2000) Activity of the glycosylating enzyme, core 2 GlcNAc (beta1,6) transferase, is higher in polymorphonuclear leukocytes from diabetic patients compared with age-matched control subjects: relevance to capillary occlusion in diabetic retinopathy. Diabetes 49:1724-1730

12. Chibber R, Ben-Mahmud BM, Mann GE, Zhang JJ, Kohner EM (2003) Protein kinase $\mathrm{C}$ beta2-dependent phosphorylation of core 2 GlcNAc-T promotes leukocyte-endothelial cell adhesion: a mechanism underlying capillary occlusion in diabetic retinopathy. Diabetes 52:1519-1527

13. Yang X, Lehotay M, Anastassiades T, Harrison M, Brockhausen I (2004) The effect of TNF-alpha on glycosylation pathways in bovine synoviocytes. Biochem Cell Biol 82:559-568

14. Ellies LG, Tsuboi S, Petryniak B, Lowe JB, Fukuda M, Marth JD (1998) Core 2 oligosaccharide biosynthesis distinguishes between selectin ligands essential for leukocyte homing and inflammation. Immunity 9:881-890

15. Tsuboi S, Fukuda M (2001) Roles of O-linked oligosaccharides in immune responses. Bioessays 23:46-53

16. Shimodaira K, Nakayama J, Nakamura N, Hasebe O, Katsuyama T, Fukuda M (1997) Carcinoma-associated expression of core 2 beta-1,6-N-acetylglucosaminyltransferase gene in human colorectal cancer: role of O-glycans in tumor progression. Cancer Res 57:5201-5206

17. Nishio Y, Warren CE, Buczek-Thomas JA et al (1995) Identification and characterization of a gene regulating enzymatic glycosylation which is induced by diabetes and hyperglycemia specifically in rat cardiac tissue. J Clin Invest 96:1759-1767

18. Higgins EA, Siminovitch KA, Zhuang DL, Brockhausen I, Dennis JW (1991) Aberrant O-linked oligosaccharide biosynthesis in lymphocytes and platelets from patients with the Wiskott-Aldrich syndrome. J Biol Chem 266:6280-6290

19. Hussain MJ, Peakman M, Gallati H et al (1996) Elevated serum levels of macrophage-derived cytokines precede and accompany the onset of IDDM. Diabetologia 39:60-69

20. Lechleitner M, Koch T, Herold M, Dzien A, Hoppichler F (2000) Tumour necrosis factor-alpha plasma level in patients with type 1 diabetes mellitus and its association with glycaemic control and cardiovascular risk factors. J Intern Med 248:67-76

21. Foss MC, Foss NT, Paccola GM, Silva CL (1992) Serum levels of tumor necrosis factor in insulin-dependent diabetic patients. Braz J Med Biol Res 25:239-242
22. Bertin E, Nguyen P, Guenounou M, Durlach V, Potron G, Leutenegger $M$ (2000) Plasma levels of tumor necrosis factor-alpha (TNF-alpha) are essentially dependent on visceral fat amount in type 2 diabetic patients. Diabetes Metab 26: $178-180$

23. Guha M, Bai W, Nadler JL, Natarajan R (2000) Molecular mechanisms of tumor necrosis factor alpha gene expression in monocytic cells via hyperglycemia-induced oxidant stressdependent and -independent pathways. J Biol Chem 275:17728-17739

24. Lin SJ, Shyue SK, Hung YY et al (2005) Superoxide dismutase inhibits the expression of vascular cell adhesion molecule-1 and intracellular cell adhesion molecule-1 induced by tumor necrosis factor-alpha in human endothelial cells through the JNK/p38 pathways. Arterioscler Thromb Vasc Biol 25:334-340

25. Kumar S, Singh BK, Kalra N et al (2005) Novel thiocoumarins as inhibitors of TNF-alpha induced ICAM-1 expression on human umbilical vein endothelial cells (HUVECs) and microsomal lipid peroxidation. Bioorg Med Chem 13:1605-1613

26. Sasakawa T, Sasakawa Y, Masunaga T et al (2005) FK506 suppresses E-selectin, ICAM-1 and VCAM-1 expression on vascular endothelial cells by inhibiting tumor necrosis factor alpha secretion from peripheral blood mononuclear cells. Cytokine 29:67-71

27. Sakurai E, Taguchi H, Anand A et al (2003) Targeted disruption of the CD18 or ICAM-1 gene inhibits choroidal neovascularization. Invest Ophthalmol Vis Sci 44:2743-2749

28. Joussen AM, Poulaki V, Mitsiades N et al (2002) Nonsteroidal anti-inflammatory drugs prevent early diabetic retinopathy via TNF-alpha suppression. FASEB J 16:438-440

29. Doganay S, Evereklioglu C, Er H et al (2002) Comparison of serum NO, TNF-alpha, IL-1beta, sIL-2R, IL-6 and IL-8 levels with grades of retinopathy in patients with diabetes mellitus. Eye 16:163-170

30. Armstrong D, Augustin AJ, Spengler R et al (1998) Detection of vascular endothelial growth factor and tumor necrosis factor alpha in epiretinal membranes of proliferative diabetic retinopathy, proliferative vitreoretinopathy and macular pucker. Ophthalmologica 212:410-414

31. Spranger J, Meyer-Schwickerath R, Klein M, Schatz H, Pfeiffer A (1995) TNF-alpha level in the vitreous body. Increase in neovascular eye diseases and proliferative diabetic retinopathy. Med Klin (Munich) 90:134-137

32. Limb GA, Chignell AH, Green W, LeRoy F, Dumonde DC (1993) Distribution of TNF alpha and its reactive vascular adhesion molecules in fibrovascular membranes of proliferative diabetic retinopathy. Br J Ophthalmol 80:168-173

33. Slepova OS, Gerasimenko VL, Zakharova GIU, Novikova-Bilak TI (2001) Comparative study of the role of cytokines in various eye diseases. 2. Diabetic retinopathy. Vestn Oftalmol (Russian) 117:35-37

34. Kumaramanickavel G, Sripriya S, Vellanki RN et al (2001) Tumor necrosis factor allelic polymorphism with diabetic retinopathy in India. Diabetes Res Clin Pract 54:89-94

35. Smith MJ, Smith BR, Lawrence MB, Snapp KR (2004) Functional analysis of the combined role of the O-linked branching enzyme core 2 beta1-6-N-glucosaminyltransferase and dimerization of P-selectin glycoprotein ligand-1 in rolling on Pselectin. J Biol Chem 279:21984-21991

36. Li F, Wilkins PP, Crawley S, Weinstein J, Cummings RD, McEver RP (1996) Post-translational modifications of recombinant P-selectin glycoprotein ligand-1 required for binding to P- and E-selectin. J Biol Chem 271:3255-13264

37. Liu ZG (2005) Molecular mechanism of TNF signalling and beyond. Cell Res 15:24-27 